\title{
Diameter-Age Relationships of Two Species of Mountain Mahogany
}

\author{
JACK D. BROTHERSON, JAMES N. DAVIS, AND LARRY GREENWOOD
}

\begin{abstract}
Diameter-age relationships of two species of mountain mahogany (true mountain mahogany and curlleaf mountain mahogany) were investigated. Data were taken from populations of true mountain mahogany in the Laramie Basin of Wyoming (Brooks 1962) and the Uintah Basin of Utah. Data for curlleaf mountain mahogany were obtained from populations in the Whitehorse mountains of Oregon, the Trout Creek mountains of Nevada (Dealy 1975) and from several areas in north-central Utah. Equations were developed for age prediction from stem diameters. Age prediction was most accurate within local population boundaries and less so when used to predict ages across population boundaries. Aspect was shown to be an important factor in influencing age prediction in curlleaf mountain mahogany.
\end{abstract}

Variations in the growth rings of trees and shrubs have been used for years as dating techniques (Douglas 1935; Glock 1937) and to gain information about climatic differences of the past (Schulman 1956; Fritts 1971; Stockton and Meko 1975; Harper 1979). Ring-width variations have also been used to assess differences in the environments of selected habitats (Ferguson and Humphrey 1959; Fritts 1962; Stockton and Fritts 1973; Fritts 1974). Although trees have been the major object of such studies (Glock 1955;

Authors are associate professor of botany and range science, Department of Botany and Range Science, Brigham Young University, Provo, Utah 84602; research scientist, Shrub Sciences Laboratory, U.S. Forest Service, Provo, Utah 84601; and range conservationist, Bureau of Land, Richfield, Utah 84701.

Manuscript received March 30, 1979.
Argeter and Glock 1965), papers dealing with shrubs can also be found (Ferguson 1958; Ferguson 1959; Ferguson and Humphrey 1959). The shrub studies have generally dealt with variations of moisture in the habitat or as aids to archaeological interpretation. Studies dealing with diameter-age relationships of shrubs and their values in the development of age-prediction models, interpretations of environmental factor differences, site-quality estimates, and measurements of successional trends are generally lessknown.

The objectives of this study were: to assess the stem diameter-age relationships in true mountain mahogany (Cercocarpus montanus) and curlleaf mountain mahogany (Cercocarpus ledifolius), to develop age prediction models from stem diameters, to assess the accurateness of the models within and between populations, and to evaluate the effects of aspect on the growth patterns of the shrubs and thus the predictive value of the models.

\section{Study Area}

The diameter-age data for true-mountain-mahogany in the Laramie Basin were taken from a population approximately 5 miles east of Laramie in a side canyon of Telephone Canyon. The population is on a south-facing slope at $2,370-\mathrm{m}$ elevation with shallow residual soils which are underlain by Casper Limestone. It lies on the steepest part of the slope and is within the $300 \mathrm{~mm}$ rainfall belt (Brooks 1962). 
The true-mountain-mahogany data from the Uintah Basin were taken from 20 populations scattered along the southern foothills of the Uinta mountains north and east of Duchesne. In the area, populations of true mountain mahogany are found at elevations ranging from 1,500 to $2,000 \mathrm{~m}$ and on sites where ledge outcroppings occur. Annual precipitation in the area is about $260 \mathrm{~mm}$ (Greenwood and Brotherson 1978).

Stem-diameter-age data from curlleaf mountain mahogany came from plants growing in one population on White Horse mountain in Malheur county, Oregon. The population lies at 1,890 $m$ elevation of a $25 \%$ northeast slope. The soil, a moderately shallow, well-drained gravelly loam is derived from basalt parent matcrial. Precipitation is estimated at $500 \mathrm{~mm}$ (Dealy 1975).

Data on curlleaf mountain mahogany from Nevada were obtained from a single population in the Trout Creek mountains on a $5 \%$ south slope at $2,000 \mathrm{~m}$ elevation. The soil was a shallow, well-drained gravelly loam with an underlying parent material of rhyalite. Precipitation is approximately $450 \mathrm{~mm}$ (Dealy 1975).

In Utah the curlleaf mountain mahogany material came from 10 populations scattered across much of central and northeastern parts of the state. The populations were located between 2,100 and $2,700 \mathrm{~m}$ elevation on slopes which varied from 18 to $80 \%$. All aspects of exposure were represented. The soils were invariably shallow and sandy loam in texture. Precipitation data are unavailable (Davis 1976).

\section{Methods}

Twelve stems of true mountain mahogany were taken from the Laramie Basin and 100 stems from the Uintah Basin. Stems were located by using a small hand saw and by cutting the individual stem off at $10 \mathrm{~cm}$ above the ground. A second cut was then made 10 $\mathrm{cm}$ above the first so that only a small length of stem was actually collected (Brooks 1962; Greenwood and Brotherson 1978). The stems pieces were then cut diagonally, polished with fine sand paper and ring-counted twice (independently) with the aid of a hand lens and/or a binocular microscope (Ferguson 1970).

Stems collected from curlleaf mountain mahogany varied in sample size, with 17 stems coming from Whitehorse mountain in Oregon, 28 stems from Trout Creek mountains in Nevada, and 50 from central and northeastern Utah. The stems from Oregon and Nevada were cut at $46 \mathrm{~cm}$ above the ground while those in Utah were cut at $30 \mathrm{~cm}$. Each stem represented one individual. Only the largest stem was cut from individuals having multiple stems. Stem cross-sections were selected from each stand to provide maximum variation in size (Dealy 1975; Davis 1976). As with true mountain mahogany, all stem cross sections were sanded and then ring counted twice to determine age. Linear regression was used to analyze all stem-diameter-age relationships.

Stem data (diameter-age information) for the Laramie Basin, the White Horse and Trout Creek mountains were taken from studies done by Brooks (1962) and Dealy (1975), whereas the material from Utah comes from studies made in conjunction with the Shrub and Rangeland Ecology Research Laboratory, Department of Botany and Range Science, Brigham Young University, Provo, Utah.

\section{Results}

\section{True Mountain Mahogany}

The stems of true mountain mahogany from the Laramie Basin ranged in diameter from 9 to $29 \mathrm{~mm}$ and in age from 17 to 37.years (Brooks 1962). Those from the Uintah Basin showed diameters ranging from 2 to $26 \mathrm{~mm}$ and ages ranging from 6 to 54 years (Greenwood and Brotherson 1978). Stem diameters (mm) were plotted against stem age (years) (Fig. 1) and regression equations were generated (Table 1). All correlation coefficients ( $r$ values) were highly significant $(p<.001)$. The Laramie Basin data showed the highest correlation coefficient with the Uintah Basin materials being

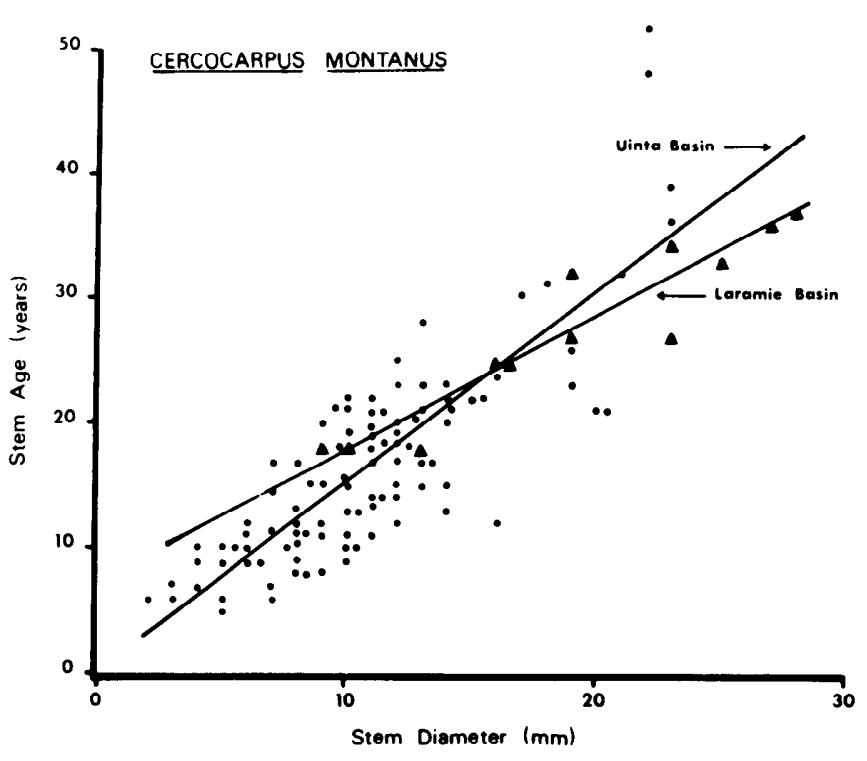

Fig. 1. Graph showing the stem diameter-age relationships of true mountain mahogany in the Laramie Basin of Wyoming and the Uintah Basin of Utah.

lower. This may be due to a much larger sample from the Uintah Basin. When the stem material from both populations was lumped and a new equation computed, the fit was inbetween those mentioned above but closer to the Uintah Basin results.

When the equations were used to estimate stem ages from original material (stems used to generate the equations as well as stems not used in equation construction), the estimated ages showed mean deviations from real ages of from 1.5 to 4.4 years (Table 2). The Laramie Basin equation predicted best when used to predict ages on stem material from Laramie, but when used to predict ages of stem material from the Uintah Basin it over predicted the ages $76 \%$ of the time by 4.4 years. The Uintah Basin equation predicted equally well either the stem material from the Uintah Basin or the Laramie Basin. When the Uintah Basin and the Laramie Basin stem material were lumped and a new equation generated, it was shown to estimate the true ages of stems from both areas equally well (Table 2) and also showed the smallest mean deviation of estimated age from real age of any of the equations except for Laramie on Laramie.

\section{Curlleaf Mountain Mahogany}

The stems of curlleaf mountain mahogany from Whitehorse mountain in Oregon ranged in diameter from 50 to $248 \mathrm{~mm}$ and in age from 36 to 129 years while those from the Trout Creek mountain site in Nevada ranged in size from 51 to $226 \mathrm{~mm}$ and in age from 38 to 125 years (Dealy 1975). Plants from Utah showed diameters ranging from 31 to 171

Table 1. Predictive equations and significance levels for stem age of true mountain mahogany as developed from stem diameter-age data taken in the Laramie Basin of Wyoming and the Uintah Basin of Utah.

\begin{tabular}{lllll}
\hline \hline Estimator description & Equation & \multicolumn{1}{c}{$r^{2}$} & Sig. level \\
\hline Uintah Basin & $Y=1.5119 x+0.1498$ & 0.6934 & .001 \\
Laramie Basin & $Y=1.0335 x+7.863$ & 0.8878 & .001 \\
$\begin{array}{l}\text { Uintah Basin- } \\
\text { Laramie Basin }\end{array}$ & $Y=1.4098 x+1.2062$ & 0.7392 & .001 \\
\begin{tabular}{l} 
Combination \\
\hline
\end{tabular}
\end{tabular}


Table 2. Predictive value of the different estimator equations for stem age on true mountain mahogany populations from the Laramie Basin of Wyoming and the Uintah Basin of Utah.

\begin{tabular}{|c|c|c|c|c|}
\hline $\begin{array}{l}\text { Estimator } \\
\text { description }\end{array}$ & $\begin{array}{l}\text { Pop } \\
\text { size }\end{array}$ & $\begin{array}{l}\% \\
\text { Over- } \\
\text { est. }\end{array}$ & $\begin{array}{l}\% \\
\text { Under- } \\
\text { est. }\end{array}$ & $\begin{array}{l}\text { Mean deviation in } \\
\text { years of estimates } \\
\text { age from real age }\end{array}$ \\
\hline Uintah Basin on Uintah Basin & 100 & 52 & 48 & $3.34 \pm 3.22$ \\
\hline $\begin{array}{l}\text { Laramie Basin or Uintah Basin } \\
\text { Uintah Basin-Laramie Basin }\end{array}$ & 100 & 76 & 24 & $4.36 \pm 3.39$ \\
\hline $\begin{array}{l}\text { Combination on Uintah Basin } \\
\text { Laramie Basin on }\end{array}$ & 100 & 50 & 50 & $2.68 \pm 4.82$ \\
\hline $\begin{array}{l}\text { Laramie Basin } \\
\text { Uintah Basin-Laramie Basin }\end{array}$ & 12 & 58 & 42 & $3.28 \pm 2.26$ \\
\hline Combination on Uintah Basin & 12 & 50 & 50 & $2.77 \pm 1.78$ \\
\hline
\end{tabular}

$\mathrm{mm}$ and ages ranging from 23 to 168 years (Davis 1976).

Stem diameter and age data were again plotted against each other (Figs. 2 and 3 ) and regression equations generated (Table 3 ). All correlation coefficients were highly sig-

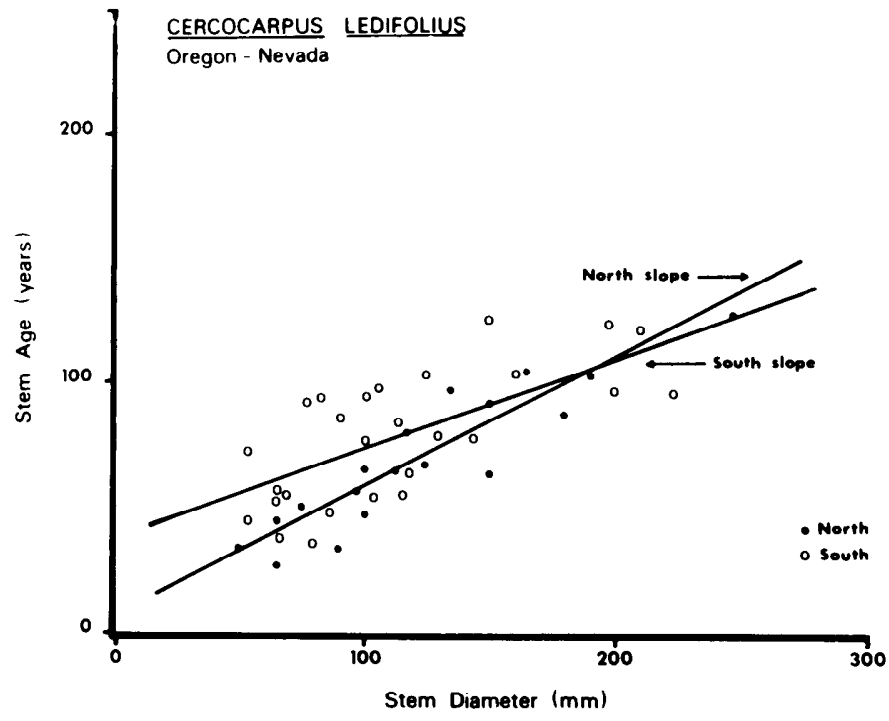

Fig. 2. Graph showing the stem diameter-age relationships of curlleaf mountain mahogany from the Whitehorse mountain sites in Oregon and the Trout Creek mountain site in Nevada.

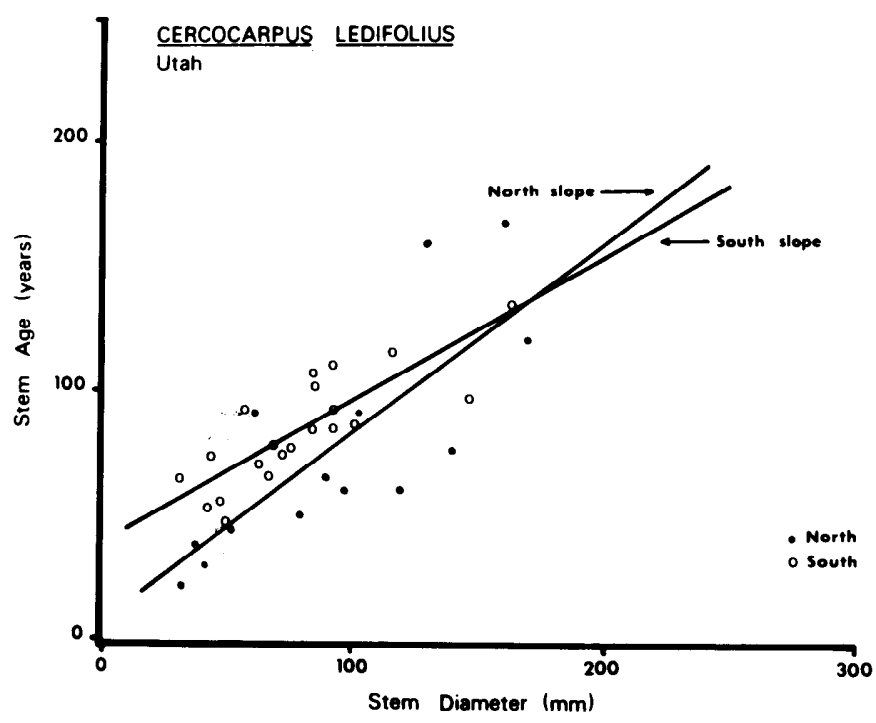

Fig. 3. Graph showing the stem diameter-age relationships of curlleaf mountain mahogany in central and northeastern Utah.
Table 3. Predictive equations and significance levels for stem age of curlleaf mountain mahogany as developed from stem diameter-age date taken in Oregon, Nevada and Utah.

\begin{tabular}{llcc}
\hline \hline Estimator description & Equation & $R^{2}$ & Sig. level \\
\hline Utah-North Slope & $Y=0.7690 x+4.6851$ & 0.6387 & .001 \\
Utah-South Slope & $Y=0.5386 x+40.8904$ & 0.6520 & .001 \\
Utah-All Slopes & $Y=0.7286 x+17.9838$ & 0.6682 & .001 \\
Oregon-North Slope & $Y=0.5030 x+7.1599$ & 0.8456 & .001 \\
Nevada-South Slope & $Y=0.3549 x+38.8008$ & 0.4894 & .001 \\
$\begin{array}{l}\text { Oregon-Nevada } \\
\text { All Slopes }\end{array}$ & $Y=0.4017 x+28.2766$ & 0.5748 & .001 \\
Utah-Oregon-Nevada & & & \\
All Slopes & $Y=0.4667 x+31.0326$ & 0.4896 & .001 \\
\hline
\end{tabular}

nificant $(p<.001)$. As with the true mountain mahogany material, several classes of equation were generated (i.e., equations specific to slope and locations, equations specific to location but of combined slope material and equations of combined location data) and then used to estimate stem ages from the stem diameter data of each of the locations sampled.

The predictive value of the equations varied greatly, ranging from a mean deviation in predicated age from real age of 8.8 years with the Oregon north slope equation predicting ages of its own material to 38.7 years when using the Utah combined material (all aspects) equation to predict the ages of the Oregon north slope stems.

The usefulness of the equations as age-predicting tools can best be assessed by examining their accuracy under a series of predictive patterns (Table 4). For example, the most reliable equations in terms of age prediction were those which were generated from single populations and then used to predict ages within that population. I ess reliable data was obtained by using equations generated in one location and then attempting to predict stem ages across population (slope to slope, etc.) or regional (Utah to Oregon, etc.) boundaries. Lumping stem data from different populations (slopes or regions (states) yielded equations with predictive value of broader application than equations developed from single population or within region material.

Table 4. Summarized predictive value of the different estimator equations for stem age of curlleaf mountain mahogany population from Oregon, Nevada and Utah.

\begin{tabular}{lcc}
\hline \hline & $\begin{array}{c}\text { Mean deviation } \\
\text { in years of } \\
\text { estimated age } \\
\text { from real age }\end{array}$ & Coef. of var. \\
\hline $\begin{array}{l}\text { Prediction pattern } \\
\text { Population on itself } \\
\text { (on stems taken from population } \\
\text { used to generate prediction } \\
\text { equation) }\end{array}$ & $13.8 \pm 10.8$ & .78 \\
$\begin{array}{l}\text { Cross population-local } \\
\text { (Utah north slope onto Utah } \\
\text { southern slope, etc.) }\end{array}$ & $17.0 \pm 28.2$ & 1.66 \\
$\begin{array}{l}\text { Combined population-local } \\
\text { (all Utah on to itself, etc.) }\end{array}$ & $15.6 \pm 11.1$ & .71 \\
$\begin{array}{l}\text { Combined population-local cross } \\
\text { region (combined Utah onto Oregon } \\
\text { and Nevada, etc.) }\end{array}$ & $27.4 \pm 19.2$ & .70 \\
$\begin{array}{l}\text { Combined region } \\
\text { (combined Utah, Oregon and Nev- } \\
\text { ada onto all material) }\end{array}$ & $18.2 \pm 12.8$ & .79 \\
\hline
\end{tabular}


Table 5. Stem diameter-age ratios for the populations of true mountain mahogany and curlleaf mountain mahogany in Utah, Wyoming, Oregon, and Nevada.

\begin{tabular}{|c|c|c|c|}
\hline Location & $\begin{array}{c}\text { Sample } \\
\text { size }\end{array}$ & $\begin{array}{c}\text { Mean dia- } \\
\text { meter } \\
(\mathrm{mm}) / \text { age } \\
\text { ratio }\end{array}$ & $\begin{array}{l}\text { Coef. } \\
\text { of var. }\end{array}$ \\
\hline Laramie Basin & 12 & $.68 \pm .10$ & .15 \\
\hline Uintah Basin & 100 & $.69 \pm .20$ & .29 \\
\hline Utah North Slope & 15 & $1.30 \pm .37$ & .28 \\
\hline Utah South Slope & 20 & $.94 \pm .24$ & .26 \\
\hline Utah All Slopes & 50 & $1.09 \pm .31$ & .28 \\
\hline Oregon North Slope & 17 & $1.81 \pm .37$ & .20 \\
\hline Nevada South Slope & 28 & $1.45 \pm .42$ & .29 \\
\hline \multicolumn{4}{|l|}{ Oregon-Nevada } \\
\hline Combination Slopes & 45 & $1.59 \pm .44$ & .28 \\
\hline
\end{tabular}

When stem-diameter to age ratios were calculated (Table 5) true mountain mahogany stems from the Uintah and Laramie basins were shown to grow at approximately the same rates. Consequently, there was little deviation in predicted age from real age (Table 2). Similar growth patterns should allow an equation when developed from data taken in one area to be of value in predicting ages of stems taken from other somewhat distant areas.

On the other hand the differential growth rates shown between populations of curlleaf mountain mahogany (Table 5) do not permit generating equations from one population or location and then using them to predict the ages of plants from populations growing in different habitats or locations. Differential growth rates with respect to curlleaf mountain mahogany are most likely due to moisture variations in the habitats of the studied populations. North slopes are known to be more moist than south slopes (Fritz 1974) and since the Oregon and Nevada populations are more northern and coastal they fall within higher moisture belts than the Utah populations (Dealy 1975).

\section{Literature Cited}

Argerter, S.R., and W.S. Glock. 1965. An Annotated Bibliography of Tree Growth and Growth Rings 1950-1962. University of Arizona Press, Tucson. $180 \mathrm{p}$.
Brooks, A.C. 1962. An ecological study of Cercocarpus montanus and adjacent communities in part of the Laramie Basin. Unpublished Master's Thesis, University of Wyoming, Laramie. 53 p.

Davis, J.N. 1976. Ecological investigations in Cercocarpus ledifolius Nutt. communities of Utah. Unpublished Master's Thesis. Brigham Young University, Provo, Utah. 56 p.

Dealy, J.E. 1975. Ecology of curlleaf mountain mahogany (Cercocarpus ledifolius Nutt.) in eastern Oregon and adjacent areas. Unpublished Ph.D. Thesis, Oregon State University, Corvallis. $162 \mathrm{p}$

Douglas, A.E. 1935. Climatic cycles and tree-growth I: A study of the annual rings of trees in relation to climate and solar activity. Carnegie Institute Washington, Publ. No. 289, Vol. I, Washington.

Ferguson, C.W. 1958. Growth rings in Big Sagebrush as a possible aid in dating archaeological sites. in a A.E. Dittert, Jr. ed. Recent developments in Navajo Project Salvage Archaeology, p. 210-211. El Palacio 65: 201-211.

Ferguson, C.W. 1959. Growth rings in woody shrubs as potential aids in archaeological interpretation. The Kiva 25: 24-30.

Ferguson, C.W. 1970. Concepts and techniques of dendrochronology,p. 183-200. in R. Berger, ed. Scientific methods in Medieval Archaeology. UCLA Center for Medieval and Renaissance Studies Contributions: IV. University of California Press, Bcrkeley, California.

Ferguson, C.W., and R.R. Humphrey. 1959. Growth rings of big sagebrush reveal rainfall records. Prog. Agr. in Arizona. 11: 3.

Fritts, H.C. 1962. The relation of growth ring widths in American beech and White oak to variations in climate. Tree-Ring Bull. 25: 2-10.

Fritts, H.C. 1971. Dendroclimatology and dendroecology. Quaternary Res. 1: 419-449.

Fritts, H.C. 1974. Relationships of ring widths in arid-site conifers to variations in monthly temperature and precipitation. Ecol. Monogr. 44: $411-440$.

Glock, W.S. 1937. Principles and methods of tree-ring analysis. Carnegie Institute Washington, Pub. No. 486, Washington. 100 p.

Glock, W.S. 1955. Tree growth II. Growth rings and climate Bot. Rev. 21: 73-188.

Greenwood, L.R., and J.D. Brotherson. 1978. Ecological relatioships between Pinyon-Juniperus and true mountain mahogany stands in the Uintah Basin, Utah. J. of Range Manage. 31: 164-167.

Harper, K.T. 1979. Dendrochronology - dating with tree rings. In W.M. Hess and R.T. Matheny eds. Science and religion: toward a more useful dialogue. Vol. 1. Paladin House Publishers, Geneva, Illinois.

Schulman, E. 1956. Dendroclimatic changes in semi-arid America. University of Arizona Press, Tucson. 142 p.

Stockton, C.W., and H.C. Fritts. 1973. Long-term reconstruction of water level changes for lake Athabaska by analysis of tree rings. Water Res. Bull. 9: 1006-27.

Stockton, C.W., and D.M. Meko. 1975. A long-term history of drought occurrence in western United States as inferred from tree rings. Weatherwise 28: $245-249$. 